\title{
PENERAPAN TEORI MULTI KECERDASAN DALAM PEMBELAJARAN BAHASA ARAB \\ (Analisis Isi Skripsi Mahasiswa Prodi PBA STAIN Batusangkar Tahun 2007-2012)
}

\author{
Yelfi Dewi S \\ Program Studi Pendidikan Bahasa Arab, Jurusan Tarbiyah, STAIN Batusangkar \\ Korespondensi: Komplek Perumahan Rizano, Cubadak, Batusangkar, Sumatera Barat \\ e-mail: yelfi_dewi@yahoo.co.id
}

\begin{abstract}
This research is aimed at investigating the implementation of multi intelligent on Arabic teaching in students' theses. The data used were students' thesis which applied experimental and classroom action research design from 2007 up to 2012. The data were then analysed by using Miles and Huberman theory. Based on analysis, it shows implementation of linguistics musical, kinaesthetic, and spatial intelligent was found in sixteen theses. Meanwhile the implementation of logical/mathematical intelligent was found in one theses. These findings conclude that seventeen theses describe the implementation of multi intelligent in Arabic learning.
\end{abstract}

Kata kunci: multi kecerdasan, pembelajaran bahasa Arab, metode, teknik, media

\section{PENDAHULUAN}

$\mathrm{S}$ eiring dengan perkembangan zaman dan tuntutan ilmu pengetahuan, dalam proses pembelajaran seorang pendidik haruslah memperhatikan peserta didik dari berbagai aspek baik fisik maupun psikis. Yang tidak kalah pentingnya adalah pada inteligensi peserta didik. Inteligensi dapat dipadan dengan kecerdasan ( $a d z-d z a k a$ '), yaitu kemampuan untuk bertindak secara terarah, berfikir secara rasional, dan berprilaku dalam menghadapi lingkungannya secara efektif. Inteligensi menggambarkan kemampuan mental seseorang yang melibatkan proses berfikir secara rasional.

Howard Gardner dengan teori multi kecerdasan (Multiple Intelligence) memetakan lingkup kecerdasan manusia menjadi delapan kategori yaitu, kecerdasan linguistik, kecerdasan matematislogis, kecerdasan spasial, kecerdasan kinestetis-jasmani, kecerdasan musikal, kecerdasan interpersonal, kecerdasan intra personal, kecerdasan naturalis (Thomas Amstrong, 2003: 34). Setiap orang memiliki kecerdasan tersebut yang berfungsi secara bersamaan dengan intensitas yang berbeda-beda pada diri setiap orang. Pada umumnya orang dapat mengembangkan setiap kecerdasan sampai pada tingkat penguasaan yang memadai apabila ia memperoleh cukup dukungan, pengayaan, dan pengajaran. Kecerdasan-kecerdasan umumnya bekerja bersamaan dengan cara yang kompleks (Thomas Amstrong, 2003: 2-3).

Banyak model pendidikan alternatif kontemporer yang pada dasarnya adalah sistem multi kecerdasan, meski 
dengan terminologi yang berbeda dan dengan tingkat penekanan yang bervariasi untuk semua kecerdasan. Teori multi kecerdasan memberikan jalan bagi pendidik untuk memikirkan metode mengajar mereka yang paling tepat. Teori tersebut juga membantu para pendidik memperkaya perbendaharaan teknik, metode, dan materi mengajar mereka sehingga dapat menjangkau kelompok siswa yang semakin luas dan beragam (Siti Khadijah, 1-2).

Program Studi Pendidikan Bahasa Arab STAIN Batusangkar memiliki prospek keahlian sebagai pendidik/guru bahasa Arab di sekolah atau madrasah. Untuk mencapai hal itu pada akhir studi, para mahasiswa dituntut menulis skripsi sebagai salah satu syarat menamatkan studi srata satu guna memperoleh gelar sarjana pendidikan Islam (S.Pd.I). Sesuai dengan profesi yang akan ditekuni nanti setelah tamat, tentunya para mahasiswa harus dibekali ilmu pendidikan dan keguruan dalam menjalani proses pembelajaran di sekolah atau madrasah tempat mereka mengajar.

Berdasarkan hasil observasi awal peneliti, banyak permasalahan yang diangkat dalam penelitian skripsi berupa kondisi pembelajaran bahasa Arab di sekolah dan madrasah. Mereka bereksperimen dan berkolaborasi dengan masyarakat sekolah untuk mengatasi permasalahan yang dihadapi. Diantaranya berkaitan dengan penggunaan metode dan strategi mengajar serta pengembangan materi atas dasar pola pikir teori multi kecerdasan. Untuk itu peneliti tertarik untuk menganalisis lebih jauh hasil penelitian mahasiswa yang tertuang dalam skripsi sebagai upaya mengungkap penerapan teori multi kecerdasan dalam pembelajaran bahasa Arab.

\section{METODE PENELITIAN}

Penelitian ini merupakan penelitian kepustakaan (Library Research) yaitu mengumpulkan data atau karya tulis ilmiah yang bertujuan untuk memecahkan suatu masalah yang pada dasarnya tertumpu pada penelaahan kritis dan mendalam terhadap bahan-bahan pustaka yang relevan. Sumber data primer penelitian ini adalah data penulisan skripsi mahasiswa Prodi PBA STAIN Batusangkar dari tahun 2007-2012 dan skripsi mahasiswa itu sendiri. Adapun skripsi yang akan diteliti dan dianalisis adalah skripsi yang membahas tentang pembelajaran bahasa Arab dan bersifat terapan dengan jenis penelitiannya adalah eksperimen, penelitian tindakan kelas (PTK). Hal ini dipilih karena dengan penggunaan jenis penelitian inilah dianggap teori multi kecerdasan itu dapat dilihat penerapannya dalam pembelajaran bahasa Arab. Adapun alasan penelitian ini difokuskan pada skripsi mahasiswa dari tahun 2007-2012 adalah karena pada tahun-tahun inilah skripsi mahasiswa banyak bercorak penelitian eksperimen dan PTK. Adapun sumber data sekunder yang menjadi pendukung adalah buku-buku yang relevan dengan kajian penelitian yaitu tentang multi kecerdasan.

Oleh karena penelitian ini adalah penelitian pustaka, maka teknik yang digunakan dalam pengumpulannya adalah survey bibliografis. Peneliti mensurvey, melacak dan memeriksa seluruh skripsi yang ditulis oleh mahasiswa prodi PBA sejak tahun 2007-2012. Ketika survey bibliografis dilakukan, pada saat yang sama, peneliti mengolah data yang dikumpulkan dengan memilah dan mengklasifikasikan skripsi berdasarkan jenis penelitian yang digunakan mahaiswa dalam skripsi tersebut yaitu eksperimen dan PTK. Data yang telah dikumpulkan kemudian diolah dengan 
cara editing, organizing, dan penemuan hasil penelitian.

Analisis data dalam penelitian kepustakaan (Library research) ini adalah analisis isi (content analysis), yaitu penelitian yang bersifat pembahasan mendalam terhadap isi suatu informasi tertulis. Atau analisis isi adalah suatu teknik penelitian untuk membuat inferensi-inferensi yang dapat ditiru (replicable)dan keshahihan data dengan memperhatikan konteksnya. Adapun tahap analisis isi yang ditempuh penulis adalah dengan langkah-langkah; pertama, menentukan permasalah, kedua, menyusun kerangka pemikiran, ketiga, menyusun perangkat metodologi, $\mathrm{Ke}$ empat, analisis data, dan kelima interpretasi data.

\section{KAJIAN TEORI}

\section{Pengertian Multi Kecerdasan}

Secara etimologi, kecerdasan merupakan kata benda yang berasal dari kata sifat, yaitu cerdas yang berarti; sempurna perkembangan akal budinya (untuk berfikir, mengerti, dsb); tajam pikiran (Depdikbud, 1997: 186). Kecerdasan atau inteligensi merupakan kata yang sering terdengar untuk menggambarkan kecerdasan seseorang.

Secara terminology, kecerdasan menurut Gardner, adalah "kemampuan untuk memecahkan atau menciptakan sesuatu yang bernilai bagi budaya tertentu. Kecerdasan sebagai kemampuan melakukan sesuatu yang bermanfaat dalam masyarakat" (Bob Samples, 141). Amstrong mengemukakan bahwa kecerdasan lebih berkaitan dengan kapasitas memecahkan masalah dan menciptakan produk di lingkungan yang kondusif dan alamiah (Thomas Amstrong, 2003: 2). Sedangkan menurut Alfred Binet dan Theodore Simon, dalam buku Agus Efendi, kecerdasan terdiri dari tiga komponen: pertama, kemampuan meng- arahkan pikiran dan tindakan. Kedua, kemampuan mengubah arah tindakan jika tindakan tersebut telah dilakukan. Ketiga, kemampuan mengkritik diri sendiri (Agus Efendi, 2005: 81).

Teori multi kecerdasan merupakan model kognitif yang berupaya menjelaskan bagaimana seseorang menggunakan berbagai kecerdasannya untuk mengatasi masalah dan menciptakan suatu produk yang bermanfaat. Berbeda dengan model lain yang berorientasi pada proses, pendekatan Gardner lebih terfokus pada bagaimana pikiran manusia mencermati dan mengolah isi dunia berupa objek, orang, dan makluk lain. Gardner memetakan lingkup kemampuan manusia yang luas menjadi delapan kategori yang komprehensif sebagai delapan "kecerdasan dasar" (Syihabuddin, 2), yang lebih lanjut akan dijelaskan pada bagian jenisjenis multi kecerdasan.

\section{Jenis-jenis Kecerdasan}

Gardner, sebagaimana dikutip oleh Syihabuddin (34-45), membuat delapan jenis atau kategori kecerdasan, sebagai berikut:

1. Kecerdasan linguistik (linguistic intelligencel adz-dzaka' al-lughawi), merupakan kemampuan manusia menggunakan kata secara efektif baik secara lisan maupun tertulis. Kecerdasan ini meliputi kemampuan memanipulasi struktur bahasa, fonologi, semantik, demensi pragmatik, dan wacana.

2. Kecerdasan logika matematis (logical-mathematical intelligencel adzdzaka' al manthiqi ar-riyadhi), yaitu kemampuan menggunakan angka dengan baik dan melakukan penalaran yang benar. Kecerdasan ini meliputi kepekaan, pemahaman pola hubngan logis, pernyataan sebab-akibat, dan cara berfikir logis yang banyak digunakan para peneliti. Proses yang digunakan dalam kecerdasan matematis-logis yang banyak digunakan 
para peneliti. Proses yang digunakan dalam kecerdasan matemetis-logis ini antara lain kategorisasi, klasifikasi, pengambilan keputusan, generalisasi, penghitungan, dan pengujian hipotesis.

3. Kecerdasan spasial (spatial intelligencel adz-dzaka' al-firaghi alfadha'i), yaitu kemampuan mempersepsi dunia spasial-visual secara akurat dan mentransformasikan persepsi visual tersebut menjadi sebuah karya nyata, misalnya dalam sebuah karya lukis atau patung. Kecerdasan ini meliputi kepekaan pada warna, garis, bentuk, ruang dan hubungan antar unsut terrsebut.

4. Kecerdasan kinestetik-jasmani (bodily-kinesthetic intelligencel adzdzaka' al-jasadi), yaitu keahlian menggunakan seluruh tubuh untuk mengekspresikan ide dan perasaan dan keterampilan menggunakan tangan untuk menciptakan atau mengubah sesuatu. Kecerdasan ini meliputi kemampuan-kemampuan fisik yang spesifik seperti koordinasi, keseimbangan, keterampilan, kekuatan, kelenturan dan kecepatan, serta kemampuan menerima rangsangan.

5. Kecerdasan musikal (Musical intelligenceladz-dzaka' al-musiqi), yaitu keahlian menangani bentukbentuk musical dengan cara mempersepsi, membedakan, mengubah, dan mengepresikan musik. Keserdasan ini meliputi kepekaan pada irama, melodi, dan warna nada atau warna suara suatu lagu.

6. Kecerdasan interpersonal (interpersonal intelligencel adz-dzaka' alijtima'i), yaitu kemampuan mempersepsi dan membedakan suasana hati, maksud, motivassi serta perasaan orang lain. Kecerdasan ini meliputi kepekaan pada ekspresi wajah, suara, gerak-isyarat, kemampuan menang- gapi secara efektif tanda tersebut dengan tindakan pragmatis tertentu.

7. Kecerdasan intrapersonal (intrapersonal intelligencel adz-dzaka'arruhi), yaitu kemampuan memahami diri sendiri dan kemampuan untuk bertindak berdasarkan pemahaman tersebut. Kecerdasan ini meliputi kemampuan memahami diri yang secara akurat, kesadaran akan suasana hati, maksud, motivasi, temperamen dan keinginan serta kemampuan berdisiplin diri, serta memahami dan menghargai diri.

8. Kecerdasan naturalis (natural intelligencel adz-dzaka'ath-thabi'i), yaitu keahlian mengenali dan mengkategorikan spesis flora dan fauna di lingkungan sekitar. Kecerdasan ini meliputi kepekaan pada fenomena alam.

\section{Integrasi Multi Kecerdasan di Ruangan Kelas}

Ciri khas penerapan multi kecerdasan dalam kelas adalah membentuk iklim kelas yang di dalamnya peserta didik merasa bebas mengambil resiko untuk menggunakan beragam kecerdasan. Adapun pendekatan yang digunakan untuk menerapkan multi kecerdasan dalam pelajaran dan di kelas adalah dengan membuat pusat-pusat belajar berbasis kurikulum, kecerdasan, proyek, pameran, presentasi.

Berikut ini akan dipaparkanenam cara yang dapat dilakukan oleh seorang guru untuk melatih dan mengembangkan multi kecerdasan di dalam ruang kelas berdasarkan jenis kecerdasan masingmasing sebagaimana dikemukan oleh Adi W. Gunawan dalam bukunya Genius Learning Strategi, petunjuk praktis untuk menerapkan Accelerated Learning:

1. Kecerdasan Linguistik; a) guru mengurangi waktu bicara dan beri kesempatan lebih banyak untuk murid berbicara, b) libatkan diskusi dan 
debat, c) beri kesempatan pada anak untuk menjelaskan sebuah pengertian dengan bahasanya sendiri, d) gunakan teknik kata atau kalimat kunci, e) ajarkan dan minta anak untuk menyusun presentasi atau makalah, f) ajarkan anak teknik berbicara dan mendengar yang baik dan benar.

2. Kecerdasanlogika matematika; a) guru menjelaskan langkah yang akan digunakan dalam mengajar dan jelaskan alasan digunakannya langkah tersebut, b) sering-sering menggunakan angka atau permainan yang melibatkan angka, c) cari hubungan antara matematika dan praktek kehidupan sehari-hari, d) ajarkan cara melakukan kategorisasi, klasifikasi, prioritas dan keterampilan memprediksi, e) ajarkan metode pemecahan masalah yang dapat digunakan dalam berbagai disiplin ilmu dan keadaan, f) promosikan perrmainan yang melibatkan kemampuan berfikir lateral.

3. Kecerdasan musikal; a) gunakan musik sebagai tanda untuk mengerjakan tugas, untuk memulai dan mengakhiri sesi pembelajaran, atau mengubah mood dan untuk meningkatkan energi atau relaksasi, b) gunakan musik untuk membantu mengingat materi, c) ajarkan dan tingkatkan ketertarikan siswa pada musik melalui pelatihan atau kegiatan ekstrakurikuler, d) beri kesempatan siswa untuk menceritakan musik kesukaannya, mengapa ia suka musik itu dan izinkan ia memainkan atau mendengarkan musik itu di kelas, e) bermain dengan musik/lagu dengan cara mengubah lirik, nada, tempo, volume atau keras-lembut, sebagai bagian dari eksplorasi ke dunia musik, f) memainkan berbagai jenis lagu atau musik dan meminta murid untuk menjelaskan apa yang mereka rasakan.

4. Kecerdasan kinestetik-jasmani; a) libatkan fisik secara umum dalam proses pembelajaran, b) lakukan rehearsal melalui gerakan, permainan peran, simulasi dan kegiatan praktis lainnya, c) berikan rehat fisik secara rutin sambil melakukan permainan, d) beri kesempatan siswa untuk mengungkapkan pengetiannya dengan membuat atau memanipulasi obyek, e) buatlah montase atau mural, f) tetapkan target untuk meningkatkan diri dalam bidang olah raga atau kecakapan yang melibatkan kemampuan koordinasi tubuh.

5. Kecerdasan spasial; a) gunakan poster atau peta pikiran sebagai referensi, b) ganti poster atau peta pikiran secara rutin, c)ajarkan cara membuat peta pikiran, poster, flowchart atau grafik untuk melengkapi kemampuan siswa dalam mencatat, d) gunakan model atau alat peraga, e) beri tugas yang melibatkan pembuatan gambar atau poster, f) gunakan tubuh sebagai alat bantu visual dan spasial dalam menyampaikan materi pembelajaran.

6. Kecerdasan naturalis; a) melakukan perjalanan ke lingkungan sekitar, seperti taman dan kebun binatang untuk pengenalan tumbuhan dan hewan, b) belajar di alam terbuka, c) mempelajari kejadian alam seperti gempa bumi, gunung meletus, hujan dan banjir, pasang surut air laut dan apa implikassinya bagi umat manusia, d) mempelajari faktor-faktor yang mempengaruhi ekosistem, e) mempelajari pengaruh perbuatan manusia terhadap alam, baik itu pengaruh positif maupun yang negatif, langsung maupun tidak langsung, f) memelihara hewan atau tanaman di sekolah/kelas dan berintegrasi dengan mereka secara rutin.

7. Kecerdasan Interpersonal; a) kembangkan kerja sama di antara siswa, b) lakukan pengelompokan secara acak maupun dengan kriteria tertentu, c) jelaskan cara melakukan pengelompokan dan ragam dari metode 
pembelajaran yang digunakan, d) ajarkan siswa bagaimana bersikap dan bermain dengan rekannya, e) tetapkan aturan kelas bersama dengan siswa, f) tetapkan tujuan pembelajaran dan bekerja bersama mencapai tujuan tersebut.

8. Kecerdasan intrapersonal; a) sediakan waktu yang cukup untuk melakukan refleksi dan berfikir, b) bersikap sabar dan menjawab pertanyaan yang bersifat terbuka dan filosofis (membutuhkan jawaban mendalam), c) pelajari filosofi untuk anaka-anak dan mulai menggunakannya sebagai tambahan materi pelajaran, d) perhatikan dan hargai perasaan dan motivasi sebagai bagian dari kesempatan berbagai cerrita, pengalama dan kesan, e) gunakan peta pikiran dan tembok aspirassi/mural. f) gunakan label positif untuk setiap anak (Adi W. Gunawan, 2012, 246-249).

Dalam referensi lain, diungkapkan strategi mengajar yang bisa dilakukan guru untuk menerapkan multi kecerdasan sebagaimana berikut (Munif Chatib dan Alamsyah Said, 2012 :8299):

1. Kecerdasan Linguistik; gunakan strategi mengajar berikut: membaca, menulis informasi, menulis naskah, wawancara, persentasi, mendongeng, bercerita, debat, membuat puisi, membuat cerpen, membuat bulletin, tanya jawab, tebak aksara, tebak kata, aksara bermakna, permainan kosa kata, pantun, melaporkan suatu peristiwa (reportase).

2. Kecerdasanlogika matematika; gunakan strategi mengajar berikut: grafik, pembuatan pola, kode, perhitungan, tebak angka, tebak symbol, diagram, hipotesis, analogi, pengukuran, berdagang (penjumlahan, pengurangan, perkalian, dan pembagain), pratikum, membuat tabel, penalaran ilmiah, klasifikasi, studi kasus, merancang eksperimen, sebab akibat, analisis data, membuat pola dalam bentuk data, menaksir data, silogisme, belajar melalui cara argumentasi dan penyelesaian masalah.

3. Kecerdasan musikal; gunakan strategi mengajar berikut: konser, bernyanyi, paduan suara atau vocal grup, konduktor (pemimpin orchestra), mencipta lagu, mengaransemen lagu, parody lagu, merancang irama lagu, menyanyi dengan gaya rap, senandung, permainan kuis "berpacu dalam melodi", tebak lagu, tebak nada, tebak irama, music alam, belajar dengan pola-pola music, ritmik, mempelajari sesuatu lewat identifikasi menggunakan panca indra.

4. Kecerdasan kinestetik-jasmani;gunakan strategi mengajar berikut: menari, pantomime, teater kelas, peragaan, acting, gerakan tubuh, melempar, kerja tangan, olah tubuh, adu kecepatan, gerakan kreatif, senam, bermain peran, simulasi (perbuatan meniru keadaan yang sebenarnya), pendidikan pertualangan, outbound, permainan melalui teknologi dan latihan-latihan fisik, belajar melalui interaksi dengan satu lingkungan tertentu, belajar lewat pengalaman nyata.

5. Kecerdasan spasial;gunakan strategi mengajar berikut: visualisasi, fotografi, dekorasi ruang, desain, penggunaan warna, melukis, sketsa gagasan, metafora warna, pameran lukisan, symbol grafis, koleksi lukisan, kaligrafi, mind mapping (gambar peta pikiran), menebak arah putaran benda, menebak arah, berkunjung ke museum, imajinasi, membanyangkan dan mendesain sampul, origami, rekreasi, belajar secara visual dan mengumpulkan ide-ide, belajar berfikir secara konsep (holistic) untuk memahami sesuatu.

6. Kecerdasan naturalis;gunakan strategi mengajar berikut: koleksi tumbuhan, 
wisata alam, penelitian lingkungan, penelitian gejala alam, penelitian anomaly cuaca, riset perilaku hewan, memelihara hewan, menghitung ranting, koleksi daun, klasifikasi (warna daun), ekostudi, menanam pohon, identifikasi (bahan alam).

7. Kecerdasan Interpersonal;gunakan strategi mengajar berikut: tenaga pemasaran (marketing day), business day, kerja kelompok, saling berbagi rasa di antara teman, kerja sama, negosiasi, melobi, permainan "kenali sekitarmu", manajemen konflik, belajar lewat interaksi dengan orang lain, belajar melalui kolaborasi dan dinamika kelompok.

8. Kecerdasan intrapersonal; gunakan strategi mengajar berikut: berbagi kasih, motivasi diri, refleksi satu menit, refleksi kegunaan (merefleksi apa yang diperoleh), ekspresikan dirimu, lihat sekitarmu, pengalaman pribadi, saling menasehati, kunjungan ke panti jompo, service learning, belajar melalui perasaan, nilai-nilai, dan sikap.

\section{HASIL PENELITIAN}

\section{Deskripsi Data}

Berdasarkan hasil pantauan dan seleksi penulis terhadap skripsi mahasiswa dari tahun 2007 sampai 2012 yang terkait dengan data penelitian ini, diperoleh skripsi sejumlah tujuh belas buah skripsi sebagaimana berikut:

1. Skripsi Munika Sari, NIM 127 018, dengan judul:

$$
\begin{aligned}
& \text { ترقية دافع التلاميذ في تعلم اللغة العربية بالألعاب } \\
& \text { اللغوية } \\
& \text { بحث عملي في المدرسة الثانوية الإسلامية الحكومية } \\
& \text { بنجيا لنتاو }
\end{aligned}
$$

(Meningkatkan motivasi siswa dalam belajar bahasa Arab dengan permainan bahasa PTK di Madrasah Tsanawiyah Negeri Pangian Lintau)

2. Skripsi Maisil Yanda, NIM 127 013, dengan judul:

$$
\text { تأثير طريقة المناقشة على مهارة الكلام }
$$

بحث بحريبي في المدرسة الثانوية الحكومية بادنج غنتنج

(Pengaruh Metode Diskusi terhadap Keterampilan Berbicara Penelitian Eksperimen di Madrasah Tsanawiyah Negeri Padang Ganting)

3. Skripsi Zetri Yuliana, NIM 127 036, dengan judul:

$$
\text { ترقية فهم المفردات بطريقة القصة }
$$

بحث عملي في المدرسة الإبتدائية قرة أعين باتو سنكر

(Meningkatkan Pemahaman Kosa Kata dengan Metode Cerita PTK Di Madrasah Ibtidaiyah Qurata A'yun Batusangkar)

4. Skripsi Rahmi Hidayat, NIM 206 107, dengan judul:

$$
\text { تأثير وسيلة ألعاب الهجاء على مهارة الكتابة }
$$

بحث بتريبي في المدرسة المتوسطة الإسلامية المحمدية

$$
\text { باتو سنكر }
$$

(Pengaruh Permainan Alphabet Terhadap Keterampilan Menulis Penelitian Eksperimen Di SMP Muhammadiyah Batusangkar)

5. Skripsi M. Badrul Munir, NIM 09 102 044, yang berjudul:

تأثير وسيلة الكلمات المتقاطعة على مهارة كتابة

$$
\text { المفردات }
$$

بحث بتريبي في المدرسة الثانوية الحكومية باتو سنكر

(Pengaruh Media Teka-Teki Silang terhadap Keterampilan Menulis Kosa kata Penelitian Eksperimen di Madrasah Tsanawiyah Negeri Batusangkar)

6. Skripsi Lathifah Bahrul, NIM 08102014, yang berjudul:

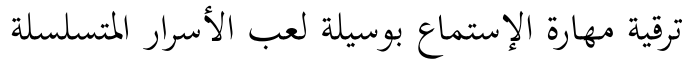




$$
\begin{aligned}
& \text { بحثث عملي في المدرسة الإبتدائية الإسلامية } \\
& \text { الحكومية سونجاى تاراب باتو سنكر }
\end{aligned}
$$

(Peningkatan Keterampilan Mendengar Dengan Media Permainan Bisik Berantai PTK di MIN Sungai Tarab Batusangkar)

7. Skripsi Zainal Abidin, NIM 127 035, yang berjudul:

$$
\begin{aligned}
& \text { تأثير طريقة الغناء على تعليم المفردات } \\
& \text { تحث تجريبي في المدرسة الإبتدائية قرة أعين باتو سنكر (Pengaruh Metode Bernyanyi Ter- } \\
& \text { hadap Pengajaran Mufradat Pene- } \\
& \text { litian Eksperimen di Madrasah } \\
& \text { Ibtidaiyah Qurata A'yun Batu- } \\
& \text { sangkar) }
\end{aligned}
$$

8. Skripsi Meliza Budiyarti, NIM 08102 017, yang berjudul:

$$
\text { ترقية مهارة الإستماع بأسلوب النشيد }
$$

بحث عملي في المدرسة الإبتدائية الحكومية الثالثة

$$
\text { بالاى - بالاى بادنج بانجج }
$$

(Peningkatan Keterampilan Mendengar Dengan Teknik Bernyanyi PTK di SDN 3 Balai-Balai Padang Panjang)

9. Skripsi Fulfina, NIM 127 005, dengan judul:

تأثير استخدام وسائل المسجلات الصوتية على تعليم

$$
\text { مهارة الاستماع }
$$

بحث بحريبي في المدرسة العالية الإسلامية الحكومية r ب باياكمبوه

(Pengaruh Penggunaan Media Rekaman terhadap Pembelajaran Keterampilan Mendengar Penelitian Eksperimen di Madrasah Aliyah Negeri 2 Payakumbuh)

10. Skripsi Nurul Muttaqin Musa, NIM 09102 045, yang berjudul:

تأثير طريقة التمثيلية على مهارة كلام التلاميذ
بحث بحريبي في المعهد الكشافن الحراء بسيبولوه كوتو

(Pengaruh Metode Drama Terhadap Keterampilan Berbicara Penelitian Eksperimen di Pesantren Pramuka Al Hira X Koto Tanah Datar)

11. Skripsi Elza Oktaria, NIM 08102 007, dengan judul:

تأثير طريقة الإستجابة الجسدية الكاملة على مهارة الإستماع

بحث بتريبي في المدرسة الثانوية الحكومية باتو سنكر (Pengaruh Metode Total Psikal Respon Terhadap Keterampilan Mendengar Penelitian Eksperimen di Madrasah Tsanawiyah Negeri Batusangkar)

12. Skripsi Novalia, NIM 206 100, dengan judul:

$$
\text { ترقية مهارة الكالام بطريقة تمثيل الأدور }
$$

بحث عملي في المعهدالعصرى المتحد تونكو لنتاو (Meningkatkan Keterampilan Berbicara dengan Metode Bermain Peran PTK di Pondik Pesantren Moderen Tuanku Lintau)

13. Skripsi Sefrinaldi, NIM 08102033 , dengan judul:

$$
\text { ترقية فهم مفردات التلاميذ بوسيلة لوحة الجيوب }
$$

بحث عملي في المدرسة الثانوية الإسلامية الحكومية<smiles>[AlH2][AlH2]</smiles>

(Peningkatan Pemahaman Kosa Kata Siswa Melalui Media Papan Kantong PTK di Madarasah Tsanawiyah Negeri Pasir Lawas)

14. Skripsi Melisa Rezi, NIM 127 015, yang berjudul:

$$
\text { ترقية مهارة الاستماع بوسيلة الأفلام عملي في المدرسة العالية الإسلامية الحكومية }
$$


(Meningkatkan Keterampilan Mendengar dengan Media Film PTK di Madrasah Aliyah Negeri Gunung Padang Panjang)

15. Skripsi Fitra, NIM 127 004, yang berjudul:

$$
\begin{aligned}
& \text { تأثير وسيلة الصور المسلسلة على فهم مقروء في } \\
& \text { تعليم اللغة العربية } \\
& \text { بحث بتريبى في المدرسة الثانوية الحكومية تالاوي }
\end{aligned}
$$

16. Skripsi Siti Erlina, NIM 206 106, yang berjudul:

$$
\begin{aligned}
& \text { ترقية قدرة التلاميذ في الإنشاء الموجة باستخدام } \\
& \text { وسيلة الصور المسلسلة } \\
& \text { بحث عملي في المدرسة العالية الحكومية سومفور } \\
& \text { بملالو }
\end{aligned}
$$

17. Skripsi Maya Susanti, NIM 127 013, yang berjudul:

$$
\begin{aligned}
& \text { تأثير استعمال وسيلة البطاقة على مهارة القراءة في } \\
& \text { تعليم اللغة العربية } \\
& \text { بحث بتربي فن المدرسة الثانوية الحكومية لوبوك } \\
& \text { باسونج }
\end{aligned}
$$

(Pengaruh Penggunaan Media Kartu terhadap Keterampilan Membaca dalam Pembelajaran Bahasa Arab Penelitian Eksperimen di Madrasah Tsanawiyah Negeri Lubuk Sikaping)

\section{Analisis Data}

Dari deskripsi data tersebut dapat dianalisis berdasakan jenis-jenis teori multi kecerdasan sebagaimana penjelasan berikut ini:

1. Analisis penerapan kecerdasan Linguistik dalam pembelajaran bahasa Arab

Pada pembelajaran bahasa Arab diterapkandiantaranya dengan permainan bahasa, permainan alphabet untuk kosa kata,pembelajaran dengan metode diskusi, dan metode cerita,sebagaimana terdapat dalam skripsi Munika Sari, Maisil yanda, Zetri Yuliana, dan Rahmi Hidayati.

2. Analisis penerapan kecerdasan Logika-Matematika dalam pembelajaran bahasa Arab

Penerapan kecerdasan ini bisa dilihat dalam pembelajaran bahasa Arab yang menggunakan media teka teki silang, sebagaimana terdapat dalam skripsi M. Badrul Munir.

3. Analisis penerapan kecerdasan Musikaldalam pembelajaran bahasa Arab

Kecerdasan ini bisa dilihat penerapannya dalam pembelajaran bahasa Arab dengan menggunakan media permainan bisik berantai, metode bernyanyi, teknik nasyid, media rekaman, sebagaimana terdapat dalam skripsi Lathifah Bahrul, Zainal Abidin, Meliza Budiyarti, Fulfina.

4. Analisis penerapan kecerdasan Kinestetik-Jasmanidalam pembelajaran bahasa Arab

Penerapan kecerdasan ini bisa dilihat dalam pembelajaran bahasa Arab yang menggunakan metode drama, metode total psikal respon, metode bermain peran, media papan kantong, sebagaimana terdapat dalam judul skripsi Nurul Muttaqin Musa, Elza Oktaria, Novalia, Sefrinaldi.

5. Analisis penerapan kecerdasan Spesial dalam pembelajaran bahasa Arab

Kecerdasan ini bisa dilihat penerapannya dalam pembelajaran 
bahasa Arab dengan menggunakan media film, media gambar berseri, media kartu, sebagaimana terdapat dalam skripsi Melisa Rezi, Fitra, Siti Erlina, Maya Susanti.

6. Analisis penerapan kecerdasan Interpersonal dalam pembelajaran bahasa Arab

Penerapan kecerdasan ini bisa dilihat dalam pembelajaran bahasa Arab dengan menggunakan metode diskusi, sebagaimana terdapat dalam skripsi Maisil Yanda.

\section{Interpretasi Data}

Dari deskripsi dan analisis data tersebut, peneliti menginterpretasikan data pada isi skripsi tersebut diantaranya sebagaimana yangakan dikemukakan berikut ini:

1. Pembelajaran bahasa Arab dengan strategiPermainan Bahasa

Kegiatan pembelajaran diawali dengan guru membacakan mufradat (kosa kata) kepada siswa, sambil bertanya jawab. Siswa dipersilahkan memilih kartu berisi kata yang disediakan guru di depan kelas, kemudian membacakan kata tersebut. Guru mengajak siswa untuk mencari lawan kata yang tertulis diatas kartu tersebut. Siswa membahasnya dan menyebutkan lawan kata tersebut sambil memperagakannya di depan kelas.

Dari kegiatan tersebut, siswa aktif dalam pembelajaran dan juga mengasah kecerdasan linguistik siswa dengan bertanya jawab, permainan kosa kata (mufradat), untuk meningkatkan perbendaharaan kosa kata siswa. Pembelajaran juga dibantu dengan media kartu, sebagai suatu upaya untuk menerapkan kecerdasan spasial dalam pembelajaran.

2. Pembelajaran bahasa Arab dengan media Teka Teki Silang untuk keterampilan menulis
Kegiatan pembelajaran diawali dengan menjelaskan skenario pembelajaran. Guru memerintahkan siswa untuk mencari informasi tentang beberapa huruf bahasa arab yang tidak bisa disambungkan dengan huruf lain dalam satu kata. Siswa menuliskan beberapa contoh dalam satu kata di papan tulis. Guru mengoreksinya sambil menerangkan beberapa huruf bahasa arab yang tidak bisa disambung dengan huruf lain dalam satu kata. Kemudian guru menerangkan cara menyambung huruf hijaiyah dengan menggunakan media teka teki silang. Siswa menulis beberapa contoh kata dalam buku catatan. Setelah itu guru memberikan latihan menulis dengan media teka teki silang untuk dikerjakan siswa. Diakhir pelajaran guru bersama siswa membahas hasil latihan yang telah dikerjakan.

Pembelajaran ini menerapkan kecerdasan logika-matematik, karena menggunakan media teka teki silang, yang terdiri dari tabel-tabel. Sekaligus juga kecerdasan linguistik, karena media teka teki silang tersebut digunakan dalam rangka pembelajaran bahasa untuk mengupayakan pencapaian kecerdasan linguistik.

3. Pembelajaran bahasa Arab dengan metode bernyanyi

Kegiatan pembelajaran diawali dengan mengajak siswa bernyanyi sesuai topik materi dalam rangka menyampaikan materi pelajaran. Siswa aktif bernyanyi bersama guru. Kemudian guru membimbing siswa menghafal kosa kata dengan cara mengulang nyanyian yang telah disajikan. Guru mengajukan beberapa pertanyaan untuk menuntun siswa aktif berbicara. Siswa menjawab pertanyaan yang diberikan guru agar dapat aktif. Setelah itu guru memberi kesempatan kepada siswa untuk 
mengungkapkan secara tepat kosa kata yang telah dinyanyikan.

Pembelajaran ini menerapkan kecerdasan musical, sekaligus juga mengembangkan kecerdasan linguistik siswa yang terlihat dari kegiatan pembelajaran dengan Tanya jawab, hafalan kosa kata.

4. Pembelajaran bahasa Arab dengan Metode Bermain Peran

Pembelajaran diawali dengan guru menyebutkan mufradat dengan intonasi yang baik dan benar, dan siswa mendengarkannya, kemudian mengulang menyebutkannya. Setelah siswa memahami mufradat tentang topik materi tersebut, maka guru mengatur skenario yang akan dimainkan oleh siswa. Kemudian guru membagi siswa menjadi dua kelompok (sesuai dengan banyaknya jumlah siswa). Siswa duduk sesuai kelompoknya dan memilih perannya masing-masing. Setelah semua siap untuk ditampilkan, maka kelompok kedua memperhatikan dengan seksama penampilan dari kelompok pertama. Kelompok kedua memberikan saran dan kritikan pada kelompok pertama yang telah tampil, dan dilanjutkan penampilan kelompok kedua, dan kelompok pertama menperhatikan serta memberi saran dan kritikan pula. Guru melakukan pengamatan selama kegiatan ini berlangsung. Setelah semuanya selesai, guru menyimpulkan dan memberi saran serta kritikan dan evaluasi untuk masing-masing kelompok.

Apabila dilihat dari metode pembelajaran yang digunakan, yaitu bermain peran, maka sudah jelas pembelajaran bahasa ini, selain bertujuan untuk mencapai kecerdasan linguistik, juga menerapkan kecerdasan kinestetik-jasmani dan kecerdasan interpersonal.

\section{PENUTUP}

\section{Kesimpulan}

Dari penjelasan terdahulu dapat disimpulkan bahwa, terdapat tujuh belas skripsi yang menjadi sumber primer penelitian ini. Semua skripsi tersebut sudah menggambarkan penerapan multi kecerdasan dalam pembelajaran bahasa Arab. Kecerdasan linguistik, kecerdasan musical, kecerdasan kinestetik-jasmani, dan kecerdasan spasial, masing-masing kecerdasan tersebutterdapat pada empat skripsi. Sehingga enam belas buah skripsi menggambarkan penerapan empat kecerdasan tersebut. Sedangkan satu buah skripsi lagi menggambarkan penerapan kecerdasan logika-matematika. Selain itu jika dilihat dari langkahlangkah pembelajarannya, juga sekaligus menggambarkan penerapan kecerdasan interpersonal.

\section{Saran}

Hasil penelitian ini menunjukkan bahwa dalam pembelajaran bahasa Arab dapat diterapkan multi kecerdasan, sebagai upaya untuk mengaktualisasikan berbagai kecerdasan siswa. Oleh karena itu, dapat dijadikan salah satu alternatif bagi guru. Dari skripsi yang dianalisis, belum terdapat penerapan kecerdasan naturalistik, dan intrapersonal dalam pembelajaran bahasa Arab, maka diharapkan kepada mahasiswa dan juga guru serta dosen bahasa Arab, hendaknya dapat menerapkan kecerdasan ini dalam proses pembelajaran. 


\section{DAFTAR RUJUKAN}

AdiW. Gunawan. 2012. Genius learning Strategy, petunjuk praktis untuk menerapkan Accelerated Learning. Jakarta: PT. Gramedia Pustaka Utama.

Agus Efendi. 2005. Revolusi Kecerdasan Abad 21, Kritik MI, EI, SQ, AQ \& Succesful Intelligence Atas IQ, Bandung: Alfabeta.

Depdikbud. 1997. Kamus Besar Bahasa Indonesia, Jakarta: Balai Pustaka.

Munif Chatib dan Alamsyah Said. 2012. Sekolah anak-anak juara berbasis kecerdasan jamak dan pendidikan berkeadilan, Bandung: Kaifa.

Syihabuddin, Pembelajaran Bahasa Arab Berbasis Kecerdasan Majemuk, Makalah disajikan dalam Seminar Nasional dan Launching Himpunan Sarjana PBA se-Indonesia, UIN Syarif Hidayatullah, Jakarta, 5 Juni 2010.

Siti Khadijah, Kecerdasan VerbalLinguistik Dalam Perspektif Pendidikan Islam Dan Model Pengembangannya Di Pondok Pesantren Darunnajah, Makalah disajikan dalam SeminarMakalah disajikan dalam Seminar Nasional dan Launching Himpunan Sarjana PBA se-Indonesia, UIN Syarif Hidayatullah, Jakarta, 5 Juni 2010.

Thomas Amstrong. 2000. SekolahParaJuara: Menerapkan Multiple Intelligences di Dunia Pendidikan terjemahan oleh Yudhi Murtanto. 2003. Bandung: Kaifa. 